\title{
Analysis of Fashionable Trends in 2020 Season Spring Summer
}

\author{
Zulfiya Zufarova and Salikh Tashpulatov* \\ Department of Technology and Design of Garments, Tashkent Institute of Textile and Light Industry, Uzbekistan
}

Submission: February 12, 2020; Published: March 02, 2020

*Corresponding author: Salikh Tashpulatov, Department of Technology and Design of Garments, Tashkent Institute of Textile and Light Industry, Republic of Uzbekistan

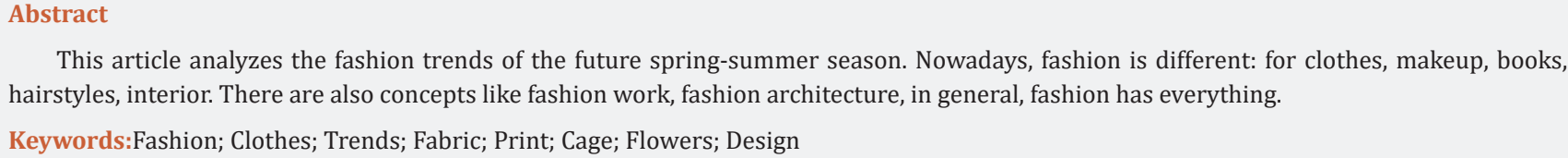

\section{Mini Review}

Today, fashion is quite a relevant phenomenon. A person needs to correspond to a certain social status, and it is fashion that helps to correctly navigate in the creation of his own style. Nowadays, fashion is different: for clothes, makeup, books, hairstyles, interior. There are also concepts like fashion work, fashion architecture, in general, fashion has everything. It is swift, today it can be one thing, and tomorrow it is completely different. Also, fashion likes to come back. What was fashionable 30years ago may become a trend tomorrow. Translated from Latin, fashion is a temporary, unstable predominance of tastes. Already in the translation itself lies the essence of this term-constant change. There are not many sayings that fashion is changeable, but the style remains with you forever. The birth of fashion occurred in France in the $14^{\text {th }}$ century. At that time, wealthy women began to wear large conical hats. People called her a hat with horns. After a while, velvet and silk began to come into fashion. The trendsetter was Venice in the $15^{\text {th }}$ century. Women wore a neckline, long trains, paid special attention to hair, wore complex high hairstyles on their heads, added hairpieces, tying them with scarves. In the middle of the $16^{\text {th }}$ century, the neckline disappears and raised collars appear. Shoes and puffy skirts are in fashion, real fashion istas and women of fashion have begun to use perfumes. Later, France begins to dictate fashion again. The laws of beauty appear, and the whole world takes the example of French women. The first editions of style and fashion appear. In the 18-19 ${ }^{\text {th }}$ century, fashion includes: flies, wigs, women's corsets, Rococo style.

Since the 20th century, fashion has begun to be dictated by designers, not by noble and wealthy people. The first fashion houses appear, over time, the rejection of corsets and long skirts begins. Since the 50's, women begin to wear trousers along with men. Jeans appeared in the 70's, a relaxed style comes into fashion. Today's fashion is changing very quickly, for each season, fashion designers come up with something new and original. For example, the famous fashion magazine Vogue every week updates the list of new trends in the fashion world. It is impossible to keep up with them unless you know the secrets of the inner kitchen - how trends are created, how designers are inspired, and by what laws the fashion industry lives on.

CEOWORLD Magazine named Istituto Marangoni the best Italian fashion school in 2018. Here they teach not to follow fashion trends, but to establish them. This article contains the popular fashion trends that can rightfully win the hearts of many fashionistas. New York, London, Milan and Paris were not greedy for fashionable discoveries, although the season cannot be called revolutionary. Next spring, you can wear any current trends, be it leather, neon, mini, feathers or suits with shorts. However, several completely new directions are absolutely obvious: the advent of tournaments and crinolines, a fascination with the history of art, a new frank sexuality, a hypertrophic evening toilet and twenty more odd moments worth paying attention to. Erdem Moralioglu, 
Demna Gvasalia and Jonathan Anderson paid special attention to the art of the past when creating collections. For example, for Erdem, the muse of the beginning of the $20^{\text {th }}$ century was Tina Modotti, a woman photographer who met Frida Kahlo and Diego Rivera. Demna created her variations on the theme of dresses with crinolines as an ode to Spanish fine art, while Anderson turned to the costume of the 16 th and 17 th centuries. Denim does not want to lose ground: next summer, designers advise wearing denim jackets on a naked body, as well as combining denim with denim of the same shade, as well as a denim shirt or jacket plus jeans of the same shade - this is one of the most popular combinations in the coming season. Denim dresses and overalls should not be forgotten either. PhilosophydilsabelMarant, Celine and Givenchy offer us to dress in jeans from head to toe.

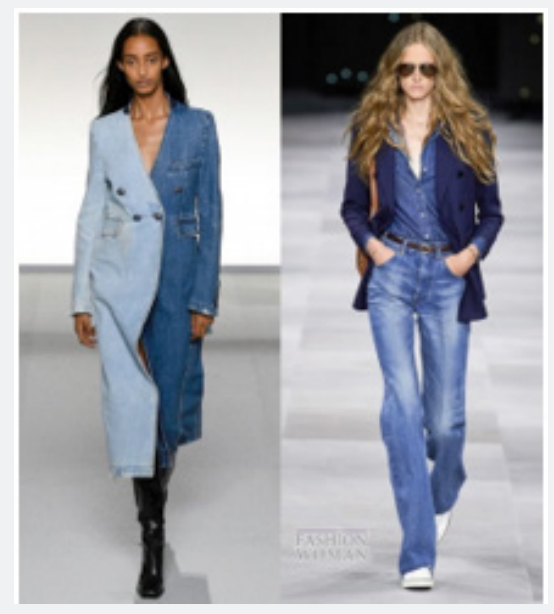

Figure 1: Denim in spring 2020 fashion-Givenchy, Celine.

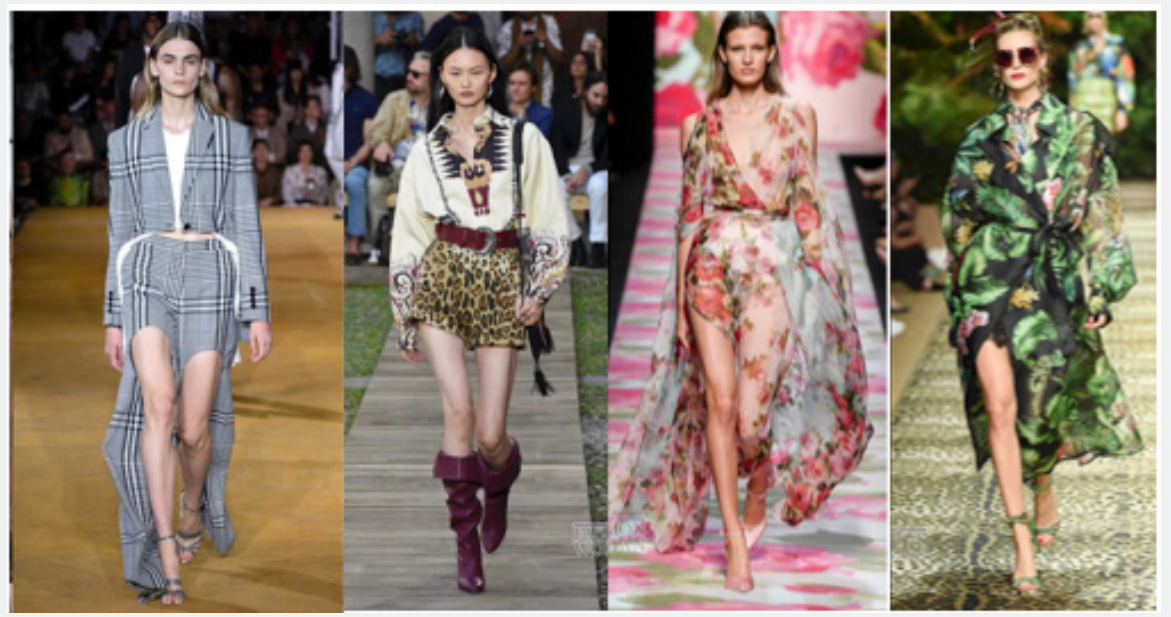

Figure 2: Various types of Prints on World Catwalks.

All shades of gold that glisten and shimmer are lifted to the fashionable Olympus. According to the designers Celine, Prada and MarcJacobs, molten metallic and "slightly wrinkled" foil - all this can be worn both on special occasions and on weekdays. The main trends on the catwalks were prints, the most strict fashion cell in black and white in the new season should certainly appear in every wardrobe. Checkered coats, tweed dresses and costumes in the spirit of Sterwell de Ville are recommended. The animal print takes an honorable second place. This print has been undermining for several seasons. Choosing clothes with an "animal" character this season, it is worth paying special attention to a zebra, python and leopard-these are the "colors" that are found most often on the catwalk. Examples are Alberta Ferretti, Etro, and Burberry. Traditionally, in spring, flowers bloom in the collections of women's clothing. Next season, floral prints will be as bright, colorful and large enough as possible. Examples are in the collections of BadgleyMischka, Fendi and Carolina Herrera. After light, weightless bright floral prints, we smoothly move on to 
the less vibrant tropical patterns. They took a special place on the catwalks. In them we can see the tropical forest with its amazing plants and outlandish inhabitants. These collections were released by Dolce \& Gabbana, Valentino and Versace. All shades of gold that glisten and shimmer are lifted to the fashionable Olympus. According to the designers Celine, Prada and MarcJacobs, molten metallic and "slightly wrinkled" foil - all this can be worn both on special occasions and on weekdays.

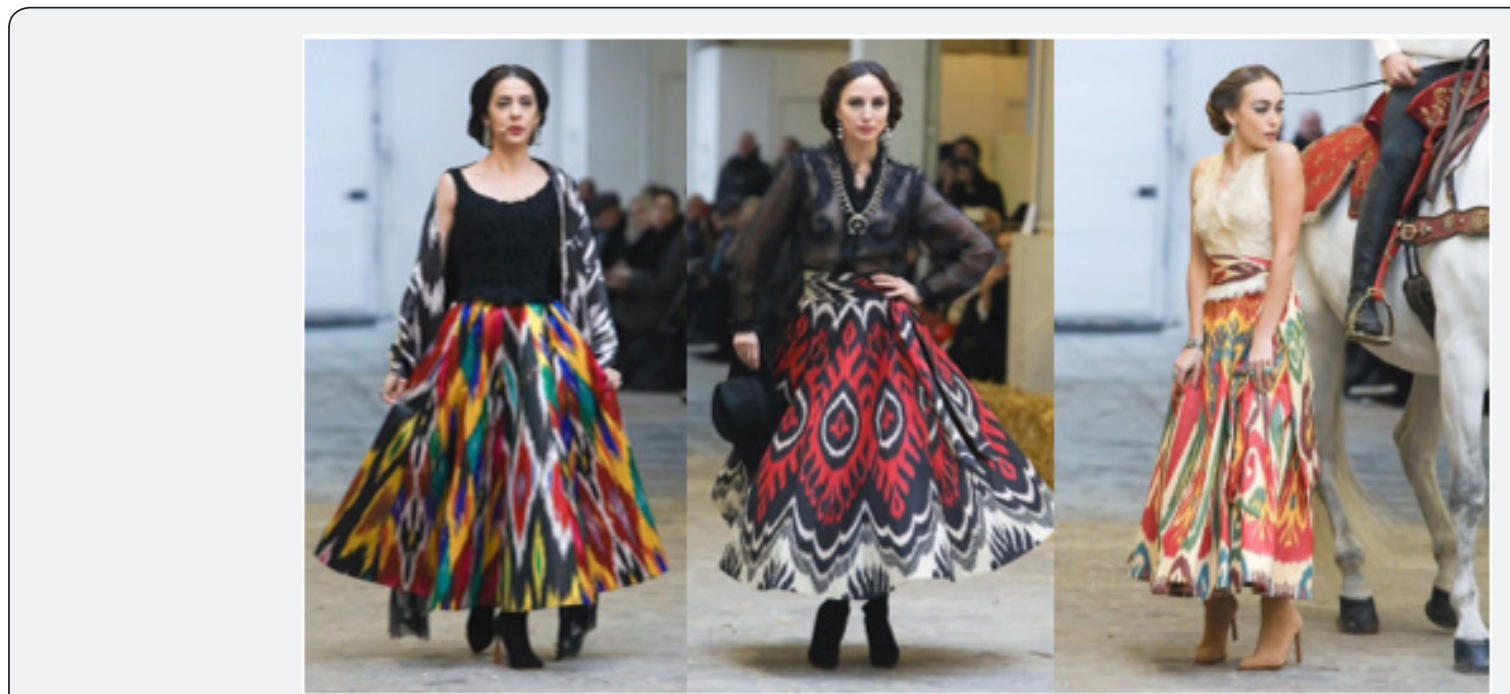

Figure 3: Using ikat to create a collection of models.

The main trends on the catwalks were prints, the most strict fashion cell in black and white in the new season should certainly appear in every wardrobe. Checkered coats, tweed dresses and costumes in the spirit of Sterwell de Ville are recommended. The animal print takes an honorable second place. This print has been undermining for several seasons. Choosing clothes with an "animal" character this season, it is worth paying special attention to a zebra, python and leopard - these are the "colors" that are found most often on the catwalk. Examples are Alberta Ferretti, Etro, and Burberry. Traditionally, in spring, flowers bloom in the collections of women's clothing. Next season, floral prints will be as bright, colorful and large enough as possible. Examples are in the collections of BadgleyMischka, Fendi and CarolinaHerrera. After light, weightless bright floral prints, we smoothly move on to the less vibrant tropical patterns. They took a special place on the catwalks. In them we can see the tropical forest with its amazing plants and outlandish inhabitants. These collections were released by Dolce \& Gabbana, Valentino and Versace. The highlight of the Paris Fashion Week was the show of a new collection of ikata from the French couturier Frank Sorbier.

Over the past couple of years, designers have increasingly begun to turn to Uzbekistan for inspiration. The prototype of Uzbek women in ethnic outfits, in particular, colorful ikat becomes the main star of world catwalks. The highlight of the Paris Fashion Week was the show of a new collection of ikata from the French couturier Frank Sorbier. Over the past couple of years, designers have increasingly begun to turn to Uzbekistan for inspiration. The prototype of Uzbek women in ethnic outfits, in particular, colorful ikat becomes the main star of world catwalks. The analysis of the fashion development trend has shown that folk motifs are of great interest, for example, the use of ikat in creating a high fashion collection. It follows that the development of effective technologies for making clothes using national fabrics is considered topical issues. Our further research will be aimed at improving existing and developing new technologies, taking into account the particularities of the materials used. 
CC (i) This work is licensed under Creative

BY DOI: 10.19080/CTFTTE.2020.06.555688
Your next submission with Juniper Publishers will reach you the below assets

- Quality Editorial service

- Swift Peer Review

- Reprints availability

- E-prints Service

- Manuscript Podcast for convenient understanding

- Global attainment for your research

- Manuscript accessibility in different formats

( Pdf, E-pub, Full Text, Audio)

- Unceasing customer service

Track the below URL for one-step submission https://juniperpublishers.com/online-submission.php 